\title{
Effect of Natural Products on the Corrosion of Titanium and Its Alloy in $\mathrm{NaOH}$ Solutions
}

\author{
Rabab M. Abou Shahba, Amal S. I. Ahmed \& Azza El-Sayed El-Shenawy \\ Department of Chemistry, Faculty of Science (Girls), Al-Azhar University \\ Cairo, Egypt
}

Waffa A. Ghannem \& Safaa M. Tantawy

Physical Chemistry Department, Central Metallurgical Research and Development Institute (CMRDI) Cairo, Egypt

\author{
Received: June 21, $2011 \quad$ Accepted: July 18, $2011 \quad$ Published: February 1, 2012 \\ doi:10.5539/ijc.v4n1p30 URL: http://dx.doi.org/10.5539/ijc.v4n1p30
}

\begin{abstract}
The corrosion behavior of pure titanium and Ti-6Al-4V alloy in different concentrations of $\mathrm{NaOH}$ was investigated by using different techniques. The effect of bovine serum albumin and egg albumin on corrosion behavior of pure titanium and Ti-6Al-4V alloy has been studied. It has been found that natural products such as (bovine serum albumin and egg albumin) inhibit the corrosion process of Ti-6Al-4V alloy more than pure titanium. The inhibition efficiency increases as the concentration of protein in the solution increases, as was confirmed by SEM.
\end{abstract}

Keywords: Egg albumin, Bovine albumin, $\mathrm{NaOH}$

\section{Introduction}

Titanium and its alloys are attractive material due to their low density, high specific strength and high corrosion resistance. It exhibits exceptional resistance to abroad range of acids, alkalis, natural waters and industrial chemicals. This is due to the formation of a productive and self-adherent oxide film, amorphous, mainly $\mathrm{TiO}_{2}$ (Young, 1961; Badawy, Felske, \& Plieth, 1989; Kozlowski, Smyrl, Atanasoska, \& Atanasoski, 1989; Schultze \& Thietke, 1989). The morphological and chemical characterization of biomimctic bone like apatite formation on alkali treated (Ti-6Al-4V) titanium alloy. This discussion is an attempt to enhance the apatite - forming ability of titanium metal induced by the alkaline $(\mathrm{NaOH})$ treatment (Faure, Balamurugan, Benhayoune, Torres, Balossier, \& Ferreira, 2009). Sul (2009) studied the electrochemical oxide growth behaviour on titanium in acid and alkaline electrolytes. The influence of proteins on the fretting-corrosion behaviour of a Ti-6Al-4V alloy was studied by Hiromoto and Mischler (2006), those proteins were found to act to as cathodic inhibitor by shifting the corrosion potential and the cathodic current towards more cathodic values. The adsorption of proteins on metal surfaces studied by ellipsometric and capacitance measurements, the effect of the nature of the metal on the amount and the configuration of adsorbed lysozyme and ovalbumin has been investigated (Bengt A. Ivarsson, Per-Olof Hegg., K. Ingemar Lundström, \& Uif Jönsoon, 1985). Titanium and titanium alloys are widely used as implant materials due to their excellent corrosion resistance and biocompatibility (Kovacs \& Davidson, 1996; Rater, Johnston, \& Lenk, 1987; Breme, 1988; Hunt \& Stoichet, 2001; Williams, 1981; Fonseca \& Barbosa, 2001; Semlitsch, Staub, \& Weber, 1985; Healy \& Ducheyne, 1992). The biocompatibility of metallic implant materials is closely related to their corrosion behavior. Corrosion and surface film dissolution are two mechanisms for introducing additional ions into the human body. It has been concluded that biocompatibility is determined, not only by corrosion products but, also, by the exchange currents and reaction products of different redox processes involving tissue compounds. It has been reported in some cases that, titanium implants (non-anodized), which have been inserted into the human body for a number of years, have shown high oxidation rates and relatively high amounts of titanium compounds have been found in tissue adjacent to the implant (Toshiaki Ohtsuka, Minoru Masuda, \& Norio Sato, 1986). By anodizing titanium previous to its implantation in the body, the corrosion rate decreases and the rate of bone healing highly increases (Arsov, Kormann, \& Plieth, 1991). 
Titanium alloys in orthopaedic implants are susceptible to mechanical disruption of the passive film in a tribo-electrochemical cell on commercial pure titanium and Ti-6Al-4V alloy in inorganic buffer solutions in the pH range from 2.0 to 12.0 and calf bovine serum at pH 4.0 and 7.0 (Contu, Elsener, \& Böhni, 2004).

The aim of the present work is to study the electrochemical behavior of pure titanium and Ti-6Al-4V alloys in $\mathrm{NaOH}$ and study the effect of proteins (bovine serum albumin and egg albumin) as corrosion inhibitor.

\section{Experimental}

Circular electrodes with working surface area of 1.14 and $1.54 \mathrm{~cm}^{2}$ for pure titanium (99.999 \%) and Ti-6Al-4V alloy respectively were used. The electrodes were fixed to glass tubing with araldite adhesive, the electrical contact was made through a thick copper wire soldered to the inner side of the electrodes. Prior to each experiment, the surface of the working electrode was performed by polishing with different grades of emery papers $(800-1200)$, then diamond past $(1 \mu \mathrm{m})$, washing by distilled water and ethanol and quickly inserted in the cell. The counter electrode was platinum sheet. The potential was recorded relative to saturated calomel electrode (SCE). Different concentrations of $\mathrm{NaOH}$ solutions $\left(1 \times 10^{-3}-6 \mathrm{M}\right)$ and different concentrations of protein additives bovine serum albumin and egg albumin (0.25-1\%), were prepared. Polentiodynamic polarization studies were carried out in the potential range $(-2000$ to $+1500 \mathrm{mV})$ at scanning rate $2 \mathrm{mV} / \mathrm{S}$. This studies were performed on electronic potentiostate (PGZ 301 Dynamic EIS Voltammetry). Polatiodynamic cyclic polarization was measured also by using electronic potentiostate (PGZ 301 Dynamic EIS voltammetry), at scanning rate $10 \mathrm{mV} / \mathrm{S}$. The cyclic polarization were swept from $(-1200$ to $+1200 \mathrm{mV})$. The surface morphology of the electrodes before and after immersion in test solutions were observed by scanning Electron Microscopy (JEOL-JSM-5410, Japan).

\section{Results and Discussion}

\subsection{Potentiodymanic polarization measurements}

Typical potentiodynamic curves of pure titanium and Ti-6Al-4V alloy were obtained in different concentrations $\left(1 \times 10^{-3}\right.$ to $\left.5 \times 10^{-1} \mathrm{M}\right)$ of aerated $\mathrm{NaOH}$ solutions. In sodium hydroxide solution an active - passive transition is observed (Contu, Elsener, \& Böhni, 2004). For both electrodes, they are representatively shown in Figures (1 and 2). As it is difficult to define a sufficient linear Tafel region in the anodic arm of the observed polarization plots, the value of the corrosion current density was obtained by using an interpolation method (Hefny, Dardir, \& Abdel-Tawab, 2004). The electrochemical parameters obtained from the polarization curves in Figures (1 and 2) are given in Table 1. The results show that the corrosion potential shifts to more negative values by increasing concentrations of alkali. Also the corrosion current ( $\mathrm{I}_{\text {corr. }}$ ) and corrosion rate (C.R) increases markedly by increasing the alkali concentration. In order to increase its corrosion resistance and application, therefore, a thin layer of titanium oxide is produced on the surface by chemical and electrochemical methods, titanium has been anodized in $20 \mathrm{M}$ of $\mathrm{NaOH}$ solution under potentiostatic conditions at constant voltage of 25 and $35 \mathrm{~V}$ (Afshar \& Vaezi, 2003).

\subsection{Potentiodynamic cyclic anodic polarization measurements}

3.2.1 Potentiodynamic cyclic anodic polarization measurements for pure $\mathrm{Ti}$ and Ti-6Al-4V alloy electrodes in $\mathrm{NaOH}$ solutions

The cyclic polarization curves of pure titanium and Ti-6Al-4V alloy in alkaline $(\mathrm{NaOH})$ solution are shown in Figures ( 3 and 4). The concentration ranges from 4 to $6 \mathrm{M}$, using scan rate $10 \mathrm{mV} / \mathrm{sec}$, in potential range from -1300 to $+1300 \mathrm{mV}$ (SCE) at room temperature. Values of associated electrochemical parameters, corrosion potential, protection potential, corrosion current, protection current, pitting current and corrosion rate are listed in Table 2. From the cyclic polarization curves Figures ( 3 and 4 ), the reverse scan came above the forward scan, indicating that the made of degradation with both pure titanium and Ti-6Al-4V alloy are due to uniform corrosion (Gurrappa \& Venugopala Reddy, 2005). From Table 2, it is clear that, corrosion potential, $\mathrm{E}_{\text {corr. }}$, protection potential $\mathrm{E}_{\mathrm{p}}$, values decreased (shift) in the negative direction by increasing the concentration of $\mathrm{NaOH}$. While the values of $\mathrm{I}_{\text {corr. }}, \mathrm{I}_{\mathrm{p}}, \mathrm{I}_{\mathrm{pit}}$ and C.R., increases in both two electrodes except in alloy, the corrosion rate (C.R.) decrease by increasing the concentration of $\mathrm{NaOH}$ solution these results indicate that the Ti-6Al-4V alloy is resistant to uniform corrosion in alkali solutions than pure Ti and may form a passive layer on the surface of the electrode. At alkaline range, it was likely that oxygen reduction was the cathodic partial reaction, while the reaction leading to the formation of $\mathrm{TiO}$ was the anodic partial reaction (Contu et al., 2004).

$$
\mathrm{Ti}+\mathrm{H}_{2} \mathrm{O} \longrightarrow \mathrm{TiO}+2 \mathrm{H}^{+}+2 \mathrm{e}^{-}
$$

The mechanism for the titanium oxide formation on $\mathrm{Ti}$ in $\mathrm{NaOH}$ solution is proposed (Pjescic, Mentus, Kommenic, \& Blagojevic, 2000). 


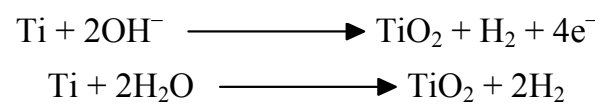

3.2.2 Effect of addition egg-albumin and bovine serum albumin on the potentiodynamic cyclic anodic polarization of pure Ti and Ti-6Al-4V alloy in $4.0 \mathrm{M} \mathrm{NaOH}$ solution

The anodic polarization curves of the two electrodes immersed in $4.0 \mathrm{M} \mathrm{NaOH}$ solution with and without different concentrations (0.25-1\%) of egg albumin and bovine serum albumin are reported in Figures (5-8). Sodium hydroxide with and without the additives of active-passive transition is observed for two test electrodes. It is clear from the curves that in pure $\mathrm{Ti}$, the area of the loop is increased by increasing the concentration of egg albumin and bovine serum albumin, but in Ti-6Al-4V alloy, the area is almost the same. Comparison of the curves plotted for pure Ti and Ti-6Al-4V alloy in $4.0 \mathrm{M} \mathrm{NaOH}$ with and without different concentrations of some proteins additive show that egg albumin and bovine serum albumin shifted corrosion and protection potential to the more negative values in case of pure $\mathrm{Ti}$ and $\mathrm{Ti}-6 \mathrm{Al}-4 \mathrm{~V}$ alloy by increasing the additives concentration. And the hysteresis loop of the reveres scan increase in case of pure Ti, but not affected in Ti-6Al-4V alloy. In contrast corrosion current, protection and pitting current decreases. It is clear from Tables (3, 4), inhibition efficiency (I.E \%) increased with increasing of protein concentration. Maximum inhibition efficiency was obtained at concentration $1.0 \% \mathrm{~V} / \mathrm{V}$ ) of egg albumin and bovine serum albumin. Ti-6Al-4V alloy was significantly more inhibited than pure Ti by the two additives, and egg albumin more efficient than bovine serum. This finding suggests that, egg albumin and bovine serum albumin behaves like as interface inhibitor that from adsorption layer interacting with the metal or alloy surface. Therefore, protein adsorbing onto the electrode surface reduce the effective surface area available for the cathodic reactions to occur (Contu et al., 2004).

\subsection{Scanning electron microscope (SEM) for Ti-6Al-4V alloy}

To confirm the degradation mechanism of Ti-6Al-4V alloy after being corroded in $\mathrm{NaOH}$ solution were observed under the scanning electron microscope (SEM). Figure $(9, \mathrm{~A}-\mathrm{C})$ illustrate the morphology surface of Ti-6Al-4V alloy specimen after potentiodynamic cyclic anodic polarization treatment in $4.0 \mathrm{M} \mathrm{NaOH}$ in presence and absence of some proteins such as (egg albumin and bovine serum albumin). As can be seen from Figure 9 (A) in $\mathrm{NaOH}$ without addition of protein, the alloy was corroded uniformly and the mode of degradation is due to uniform corrosion, while Figure 9 (B) and (C) show the optical micrographs for the alloy surface in $4.0 \mathrm{M} \mathrm{NaOH}$ solution containing $1 \%$ of both proteins. The effect of both proteins adsorbs onto the electrode surface. Therefore, protein molecules adsorbing onto the electrode surface reduce the effective surface area available for the cathodic reactions to occur. Egg albumin and bovine serum behaves like a corrosion inhibitor in sodium hydroxide. The inhibition efficiencies of egg albumin are higher than bovine serum. These results were supported by the reported data for the alloy in Table 4. SEM results are in good agreement with the cyclic polarization data. The structure and thickness of the anodic layer depend on the type of solution and the anodizing method (galvanostatic or potentiostatic). Thick anodic layers are producwd in concentrated basic solutions ( $\mathrm{pH}>13$ ) (Hugot-Le Goff, 1996).

\section{Conclusion}

1) The effect of $\mathrm{NaOH}$ solutions on the behaviour of two electrodes (pure titanium and Ti-6Al-4V alloy) were investigated by potentiodynmaic polarization, corrosion potential shifts to more negative values by increasing its conc., and also $\mathrm{I}_{\text {corr. }}$ Increases markedly by increasing the alkali concentration.

2) The potentiodynamic cyclic anodic polarization technique were carried and for pure titanium and Ti-6Al-4V alloy in different conc. of $\mathrm{NaOH}$ solutions, the results indicated that the mode of degradation with both pure $\mathrm{Ti}$ and Ti-6Al-4V alloy are due to uniform corrosion.

3) The natural products, egg albumin and serum behaves similarly to an inhibitor. It is clear from the results of $\mathrm{NaOH}$ solutions containing different concs. from egg albumin and bovine serum that, Ti-6Al-4V alloy was significantly none inhibited than pure titanium. These results were confirmed by using scanning electron microscope (SEM).

\section{References}

Afshar, A., \& Vaezi, M. R. (2003). Anodizing of titanium in naoh solution and its corrosion resistance in pbs physiologic solution. Scientia Iranica, 10(3), 361-366.

Arsov, L. D., Kormann, C., \& Plieth, W. (1991). Anodic oxidation and kinetics of titanium in $1 \mathrm{M}$ chloride solutions. J.Electrochem.Soc., 138(10), 2964. http://dx.doi.org/10.1149/1.2085349 
Badawy, W. A., Felske, A., \& Plieth, W. J. (1989). Electrochemical and photoelectrochemical behaviour of passivated $\mathrm{Ti}$ and $\mathrm{Nb}$ in nitric acid. Electrochim. Acta, 34(12), 1711-1715. http://dx.doi.org/10.1016/0013-4686(89)85053-4

Bengt A. Ivarsson, Per-Olof Hegg., K. Ingemar Lundström, \& Uif Jönsoon. (1985). Adsorption of proteins on metal surfaces studied by ellipsometric and capacitance measurements. Colloids and Surfaces, 13, 169-192. http://dx.doi.org/10.1016/0166-6622(85)80015-9

Breme, J. (1988). in: Lacombe (Ed.), Sixth world conference on Titanium, cannes, 533.

Contu, F., Elsener B., \& Böhni, H. (2004). A study of the potentials achieved during mechanical abrasion and the repassivation rate of titanium and Ti6Al4V in inorganic buffer solutions and bovine serum. Electrochimica Acta, 50(1), 33-41. http://dx.doi.org/10.1016/j.electacta.2004.07.024

Contu, F., Elsener, B., \& Böhni, H. (2004). Corrosion Science, 46(9), 2241-2254. http://dx.doi.org/10.1016/j.corsci.2004.01.005

Faure, J., Balamurugan, A., Benhayoune, Torres, P., Balossier G., \& Ferreira, J. M. F. (2009). Morphological and chemical characterisation of biomimetic bone like apatite formation on alkali treated Ti6Al4V titanium alloy. Materials Science and Engineering: C, 29(4), 1252-1257. http://dx.doi.org/10.1016/j.msec.2008.09.047

Fonseca, C., \& Barbosa, M. A. (2001). Corrosion behaviour of titanium in biofluids containing $\mathrm{H}_{2} \mathrm{O}_{2}$ studied by electrochemical impedance spectroscopy. Corros. Sci., $43(3), \quad$ 547-559. http://dx.doi.org/10.1016/S0010-938X(00)00107-4

Gurrappa, I., \& Venugopala Reddy, D. (2005). Characterisation of titanium alloy, IMI-834 for corrosion resistance under different environmental conditions. Journal of Alloys and compounds, 390(1-2), 270-274. http://dx.doi.org/10.1016/j.jallcom.2004.08.040

Healy, K. E., \& Ducheyne, P. (1992). The mechanisms of passive dissolution of titanium in a model physiological environment. J. Biomed Mater. Res., 26(3), 319-338. http://dx.doi.org/10.1002/jbm.820260305

Hefny, M. M., Dardir, A. A., \& Abdel-Tawab, A. (2004). Journal of Corrosion Science and Engineering, 7, 500-511.

Hiromoto, S., \& Mischler, S. (2006). The influence of proteins on the fretting-corrosion behavior of a Ti6Al4V alloy. WEAR, 261(9), 1002-1011. http://dx.doi.org/10.1016/j.wear.2006.03.032

Hugot-Le Goff, A. (1996). Structure of very thin $\mathrm{TiO}_{2}$ films studied by Raman spectroscopy with interference enhancement. Thin Solid Films, 142(2), 193-197. http://dx.doi.org/10.1016/0040-6090(86)90004-0

Hunt, J. A., \& Stoichet, M. (2001). Biomaterials: surface interactions. Current Opinion in Solid State and Materials Sci., 5(2-3), 161162. http://dx.doi.org/10.1016/S1359-0286(01)00012-2

Kovacs, P., \& Davidson, J. A. (1996). in: S.A. Brown, J. E. Lemons, (Eds.), Medical Applications of Titanium and Its alloys: the materials and biological issues, ASTM STP 1272, 163.

Kozlowski, M., Smyrl, W. H., Atanasoska L. J., \& Atanasoski, R. (1989). Local film thickness and photoresponse of thin, anodic $\mathrm{TiO}_{2}$ on polycrystalline titanium, Electrochim. Acta, 34(12), 1763-1768. http://dx.doi.org/10.1016/0013-4686(89)85062-5

Lemons, J. E., \& Lucas, L. C. (1986). Propert. Biomaler. J. Arthroplast, 1, 143.

Pjescic, J., Mentus, S., Kommenic, V., \& Blagojevic, N. (2000). Electrochemical and Corrosion Behaviour of Commercially and Analytically Pure Titanium in Alkaline Solutions. Journal of Corrosion Science and Engineering, 3, 331-337.

Rater, B. D., Johnston, A. B., \& Lenk, T. J. (1987). Tissue biocompatibility of kevlar aramid fibers and polymethylmethacrylate, composites in rabbits. J. Biomed. Mater. Res., 21(1), 59-64. http://dx.doi.org/10.1002/jbm.820210110

Schultze, J. V., \& Thietke, J. (1989). Local photocurrent and high power density investigations of oxide films on valve metals with focused laser beam. Electrochim Acta, 34(12), 1769-1774. http://dx.doi.org/10.1016/0013-4686(89)85063-7

Semlitsch, M., Staub, F., \& Weber, H. (1985), Titanium-aluminum - niobium alloy development for biocompatible, high strength surgical implants. Biomed. Technol., 30, 334.

Sul, Y. (2009). The electrochemical oxide growth behaviour on titanium in acid and alkaline electrolytes. Medical Engineering and Physics, 23(5), 329-346. http://dx.doi.org/10.1016/S1350-4533(01)00050-9 
Toshiaki Ohtsuka, Minoru Masuda, \& Norio Sato. (1986). Raman spectra of the anodic oxide film on Titanium in acidic sulfate and neutral phosphate solutions. J. Electrochem. Soc., 133(12), 2473-24776. http://dx.doi.org/10.1149/1.2108452

Williams, D. F. (1981). in: Williams (Ed.), Biocompatibility of clinical implant materials. CRC press. Boc.-Raton, FL. 45.

Young, L. (1961). Anodic oxide films, Acad. Press, London.

Table 1. The electrochemical parameters of pure titanium and (Ti-6Al-4V) alloy electrodes in different concentrations of $\mathrm{NaOH}$ solutions

\begin{tabular}{|c|c|c|c|c|c|c|}
\hline \multirow{2}{*}{ Electrodes } & \multirow{2}{*}{ Conc. M } & \multirow{2}{*}{$\begin{array}{c}\mathbf{E}_{\text {corr. }} \\
\mathbf{m V}\end{array}$} & \multirow{2}{*}{$\begin{array}{c}\mathbf{I}_{\text {corr. }} \\
\mathrm{mA}^{2} / \mathrm{cm}^{2}\end{array}$} & \multicolumn{2}{|c|}{ Tafel slopes } & \multirow{2}{*}{$\begin{array}{c}\text { Corrosion } \\
\text { rate(C.R.) } \mu \mathrm{m} / \mathrm{y}\end{array}$} \\
\hline & & & & $\beta_{a}$ & $\beta_{c}$ & \\
\hline \multirow{4}{*}{$\begin{array}{c}\text { Pure } \\
\text { Titanium }\end{array}$} & 0.5 & -958.5 & 3.5006 & 395.90 & -490.00 & 40.94 \\
\hline & 0.1 & -957.3 & 0.0033 & 301.50 & -277.10 & 38.61 \\
\hline & 0.01 & -929.9 & 0.0006 & 431.70 & -195.50 & 7.098 \\
\hline & 0.001 & -735.4 & 0.0002 & 327.10 & -171.00 & 2.112 \\
\hline \multirow{4}{*}{$\begin{array}{c}\text { (Ti-6Al-4V) } \\
\text { Alloy }\end{array}$} & 0.5 & -858.0 & 52.71 & 3001.6 & -2257.4 & 616.6 \\
\hline & 0.1 & -448.3 & 31.74 & 4183.5 & -1480.5 & 371.2 \\
\hline & 0.01 & -396.7 & 25.96 & 3472.2 & -2813.7 & 303.7 \\
\hline & 0.001 & -367.3 & 19.18 & 5619.3 & -2745.3 & 224.3 \\
\hline
\end{tabular}

Table 2. The corrosion parameters of pure titanium and (Ti-6Al-4V) alloy electrodes in different concentration of $\mathrm{NaOH}$ solution

\begin{tabular}{|c|c|c|c|c|c|c|c|}
\hline Electrodes & Conc. $\mathbf{M}$ & $\begin{array}{c}\mathbf{E}_{\text {corr }} \\
\mathbf{m V}\end{array}$ & $\begin{array}{c}\mathbf{E}_{\text {protect }} \\
\mathbf{m V}\end{array}$ & $\begin{array}{c}\mathbf{I}_{\text {corr. }} \\
\mathbf{m A} / \mathbf{c m}^{2}\end{array}$ & $\begin{array}{c}\mathbf{I}_{\text {protect }} \\
\mathbf{m A} / \mathbf{c m}^{2}\end{array}$ & $\begin{array}{c}\mathbf{I}_{\text {pit }} \\
\mathbf{A} / \mathbf{c m}^{2}\end{array}$ & $\begin{array}{c}\text { Corrosion rate } \\
\mathbf{( C . R . )} \mathbf{~} \mathbf{m} / \mathbf{y}\end{array}$ \\
\hline \multirow{3}{*}{ Pure Titanium } & 4.0 & -822.70 & -0.6169 & 102.7229 & 3.691 & 2.946 & 120.1 \\
\cline { 2 - 8 } & 5.0 & -1000.7 & -0.9282 & 196.8602 & 4.408 & 3.569 & 230.2 \\
\cline { 2 - 8 } & 6.0 & -1031.3 & -0.956 & 205.3385 & 4.622 & 3.700 & 240.0 \\
\hline \multirow{3}{*}{ Titanium alloy } & 4.0 & -574.0 & -0.2668 & 3.234100 & 1.548 & 2.372 & 160.9 \\
\cline { 2 - 8 } & 5.0 & -714.70 & -0.5224 & 16.20310 & 3.138 & 3.870 & 189.5 \\
\cline { 2 - 8 } & 6.0 & -974.9 & -0.8781 & 137.6454 & 3.317 & 4.040 & 37.82 \\
\hline
\end{tabular}

Table 3. The corrosion parameters of pure titanium electrode in $4.0 \mathrm{M} \mathrm{NaOH}$ solution containing different concentrations of both egg albumin and serum bovine albumin

\begin{tabular}{|c|c|c|c|c|c|c|c|c|}
\hline $\begin{array}{c}\text { Type of } \\
\text { proteins }\end{array}$ & Conc.\% & $\begin{array}{l}E_{\text {corr }} \\
\mathbf{m V}\end{array}$ & $\begin{array}{c}\mathbf{E}_{\text {protect }} \\
\mathbf{m V}\end{array}$ & $\begin{array}{c}I_{\text {corr. }} \\
\mathrm{mA} / \mathrm{cm}^{2}\end{array}$ & $\begin{array}{c}\mathbf{I}_{\text {protect }} \\
\mathbf{m A} / \mathbf{c m}^{2}\end{array}$ & $\begin{array}{c}\mathbf{I}_{\text {Pit }} \\
\mathbf{m A} / \mathbf{c m}^{2}\end{array} \mid$ & $\begin{array}{c}\text { Corrosion rate (C.R.) } \\
\mu \mathrm{m} / \mathbf{y}\end{array}$ & $\begin{array}{c}\text { Inhibition } \\
\text { Efficiently I.E \% }\end{array}$ \\
\hline \multirow{4}{*}{$\begin{array}{c}\text { egg } \\
\text { Albumin }\end{array}$} & 0 & -822.70 & -0.6169 & 102.7229 & 3.691 & 2.946 & 120.1 & - \\
\hline & 0.25 & -892.40 & -0.7892 & 37.71600 & 3.922 & 3.376 & 112.7 & 6.160 \\
\hline & 0.5 & -116.80 & -1.0390 & 24.35710 & 4.030 & 3.503 & 99.80 & 17.38 \\
\hline & 1 & -1159.8 & -1.1060 & 18.78710 & 4.113 & 3.779 & 95.22 & 20.71 \\
\hline \multirow{4}{*}{$\begin{array}{c}\text { Serum } \\
\text { bovine } \\
\text { Albumin }\end{array}$} & 0 & -822.70 & -0.6169 & 102.7229 & 3.691 & 2.946 & 120.1 & - \\
\hline & 0.5 & -862.90 & -0.6990 & 37.28450 & 3.850 & 3.442 & 110.8 & 7.740 \\
\hline & 0.75 & -926.20 & -1.0080 & 35.14020 & 3.900 & 3.478 & 98.70 & 17.81 \\
\hline & 1 & -1183.0 & -1.01280 & 15.88870 & 4.000 & 3.550 & 92.50 & 22.98 \\
\hline
\end{tabular}


Table 4. The corrosion parameters of $\mathrm{Ti}$ alloy electrode in $4.0 \mathrm{M} \mathrm{NaOH}$ solution containing different concentrations of both egg albumin and serum bovine albumin

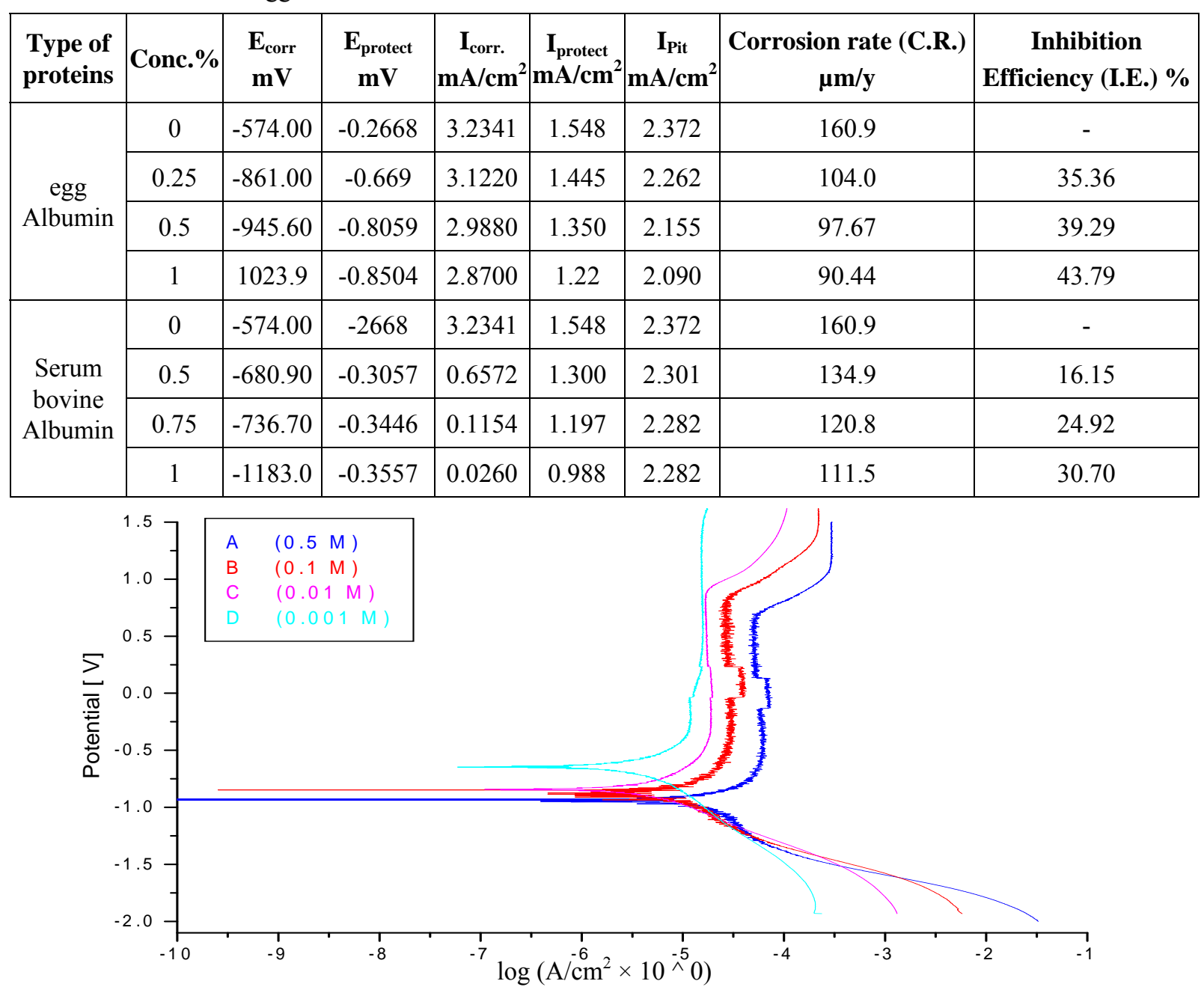

Figure 1. Potentiodynamic polarization curves of pure titanium electrode in different concentrations of $\mathrm{NaOH}$ solutions

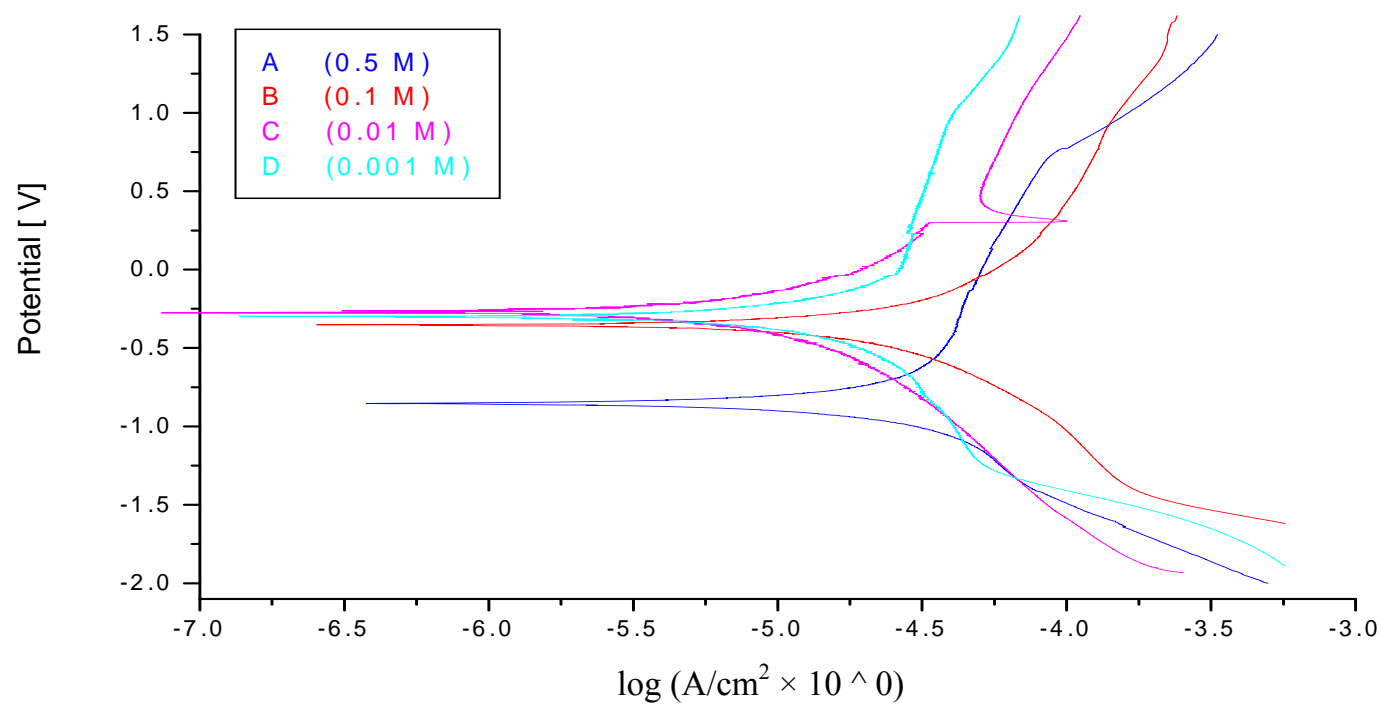

Figure 2. Potentiodynamic polarization curves of titanium alloy electrode in different concentrations of $\mathrm{NaOH}$ solutions 


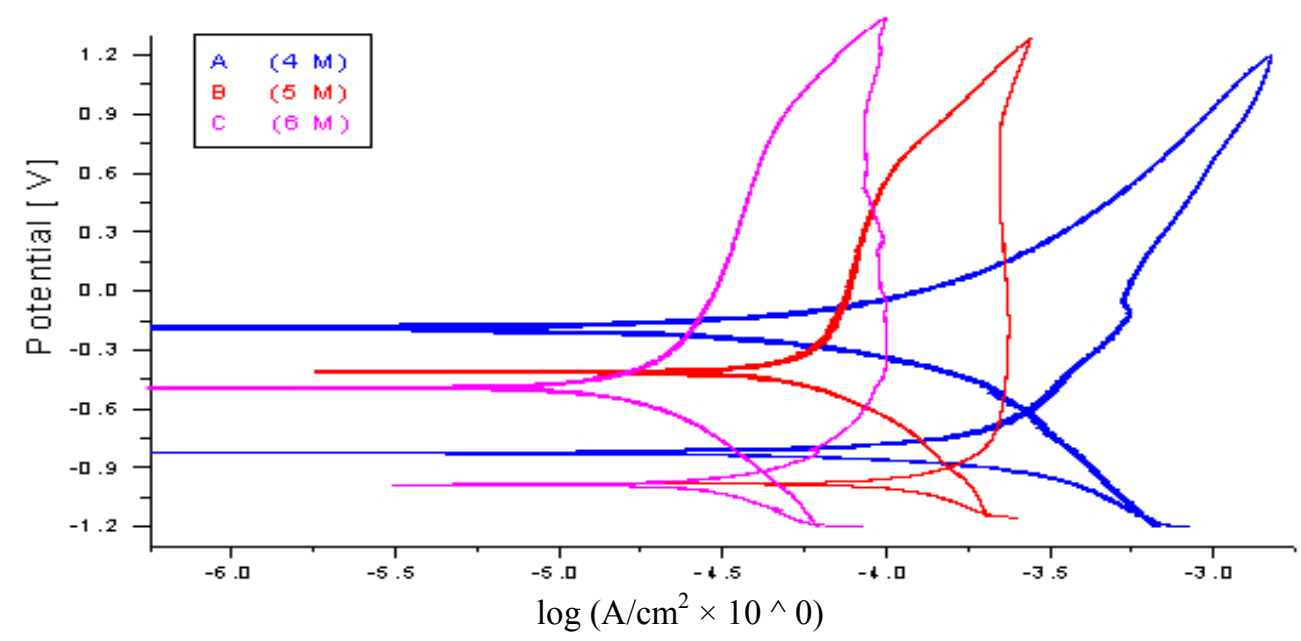

Figure 3. Cyclic anodic polarization curves of pure titanium electrode in different concentrations (4-6 M) of sodium hydroxide solutions

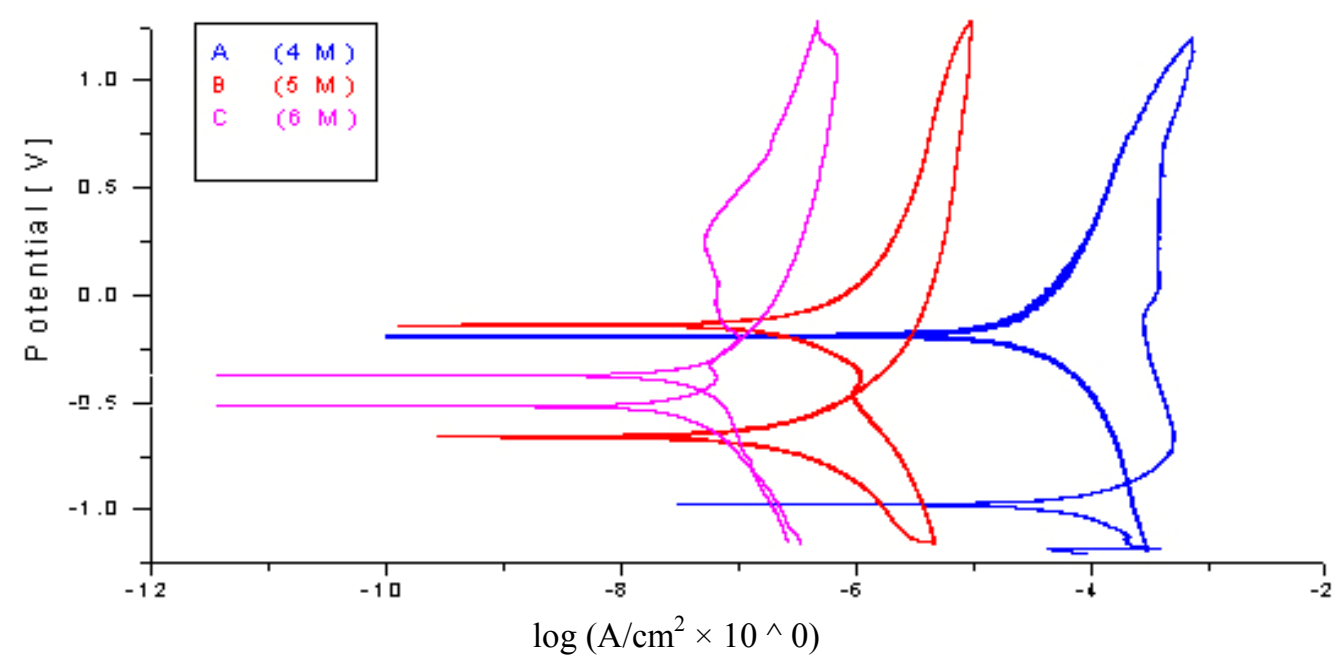

Figure 4. Cyclic anodic polarization curves of of titanium alloy electrode in different concentrations $(4-6 \mathrm{M})$ of sodium hydroxide solutions

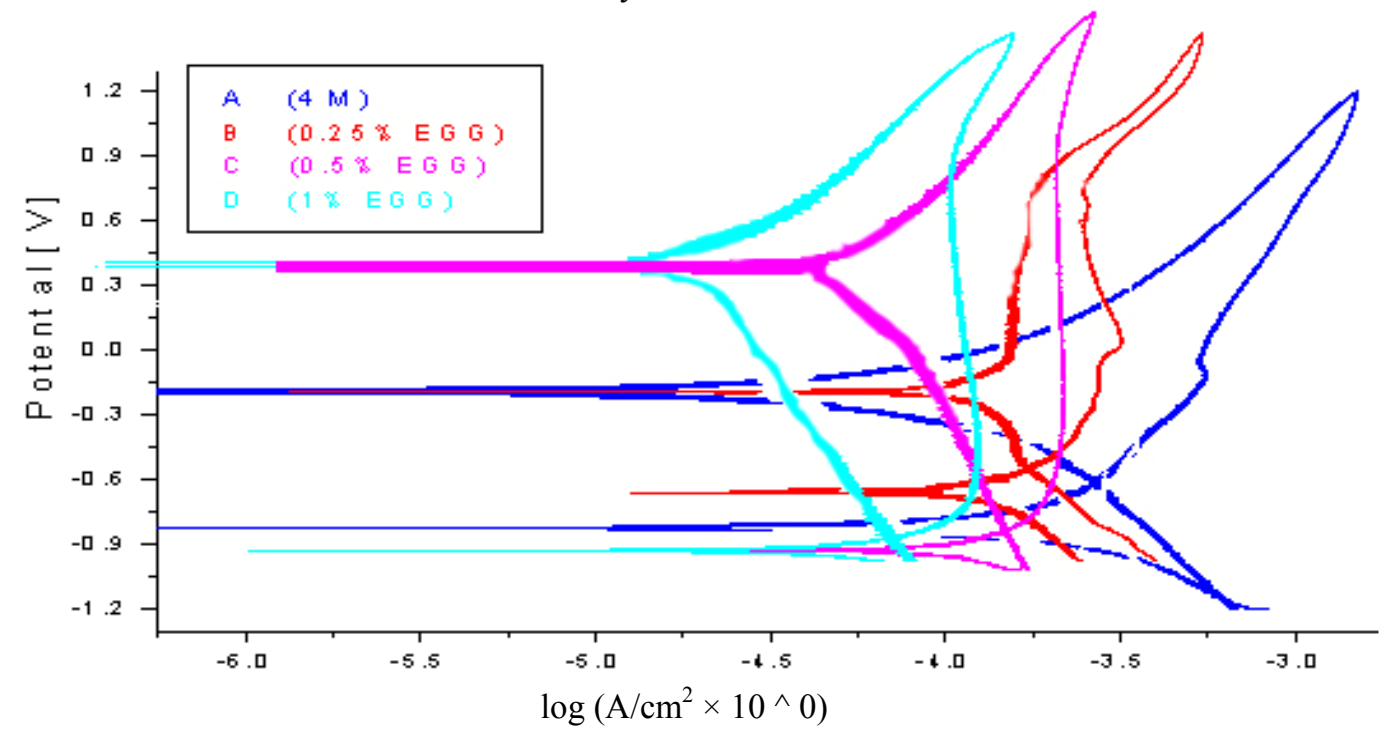

Figure 5. Cyclic anodic polarization curves of pure titanium electrode in $(4 \mathrm{M}) \mathrm{NaOH}$ with and without different percentage $(0.25-1 \%)$ of egg albumin 


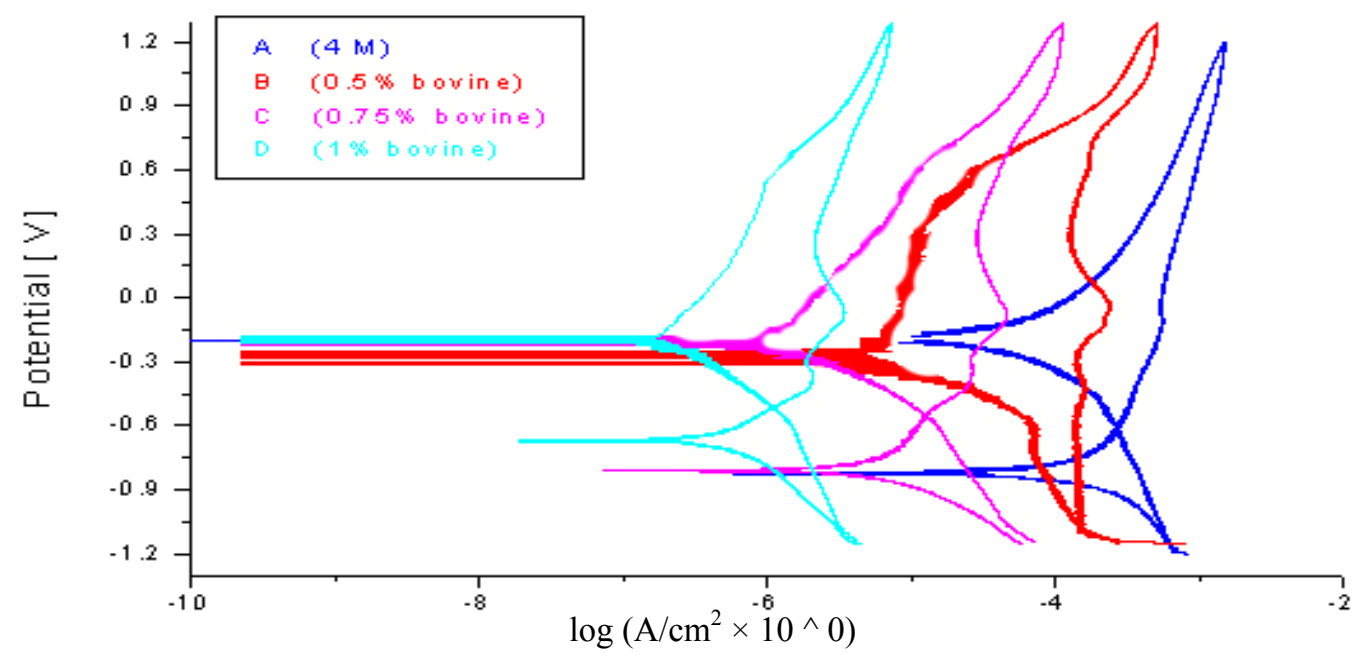

Figure 6. Cyclic anodic polarization curves of pure titanium electrode in $(4 \mathrm{M}) \mathrm{NaOH}$ with and without different percentage $(0.5-1 \%)$ of bovine serum albumin

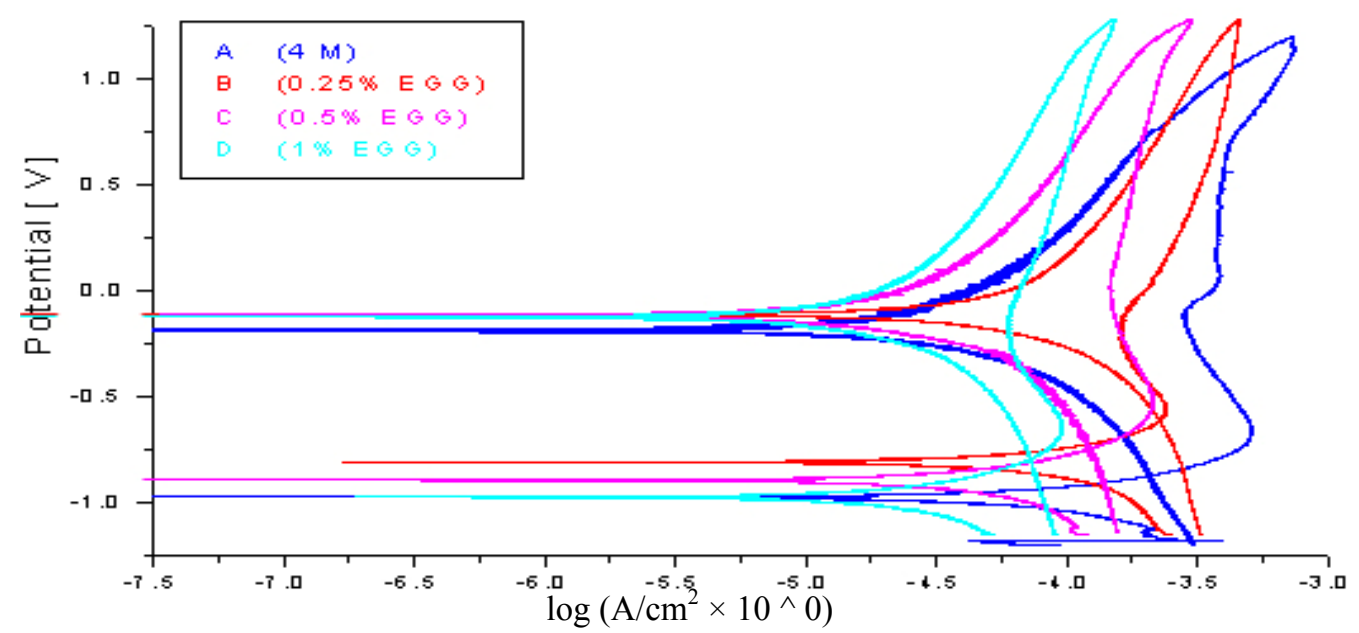

Figure 7. Cyclic anodic polarization curves of titanium alloy electrode in $(4 \mathrm{M}) \mathrm{NaOH}$ with and without different percentage $(0.25-1 \%)$ of egg albumin

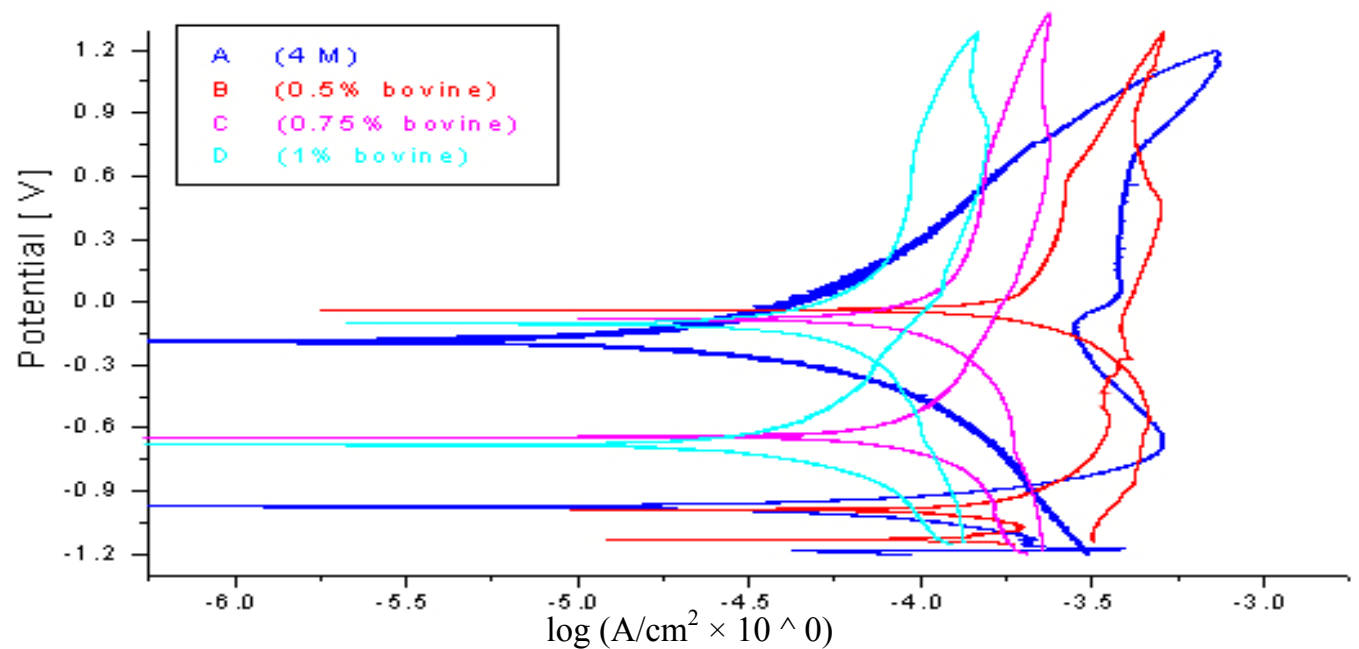

Figure 8. Cyclic anodic polarization curves of titanium alloy electrode in $(4 \mathrm{M}) \mathrm{NaOH}$ with and without different percentage $(0.5-1 \%)$ of bovine serum albumin 


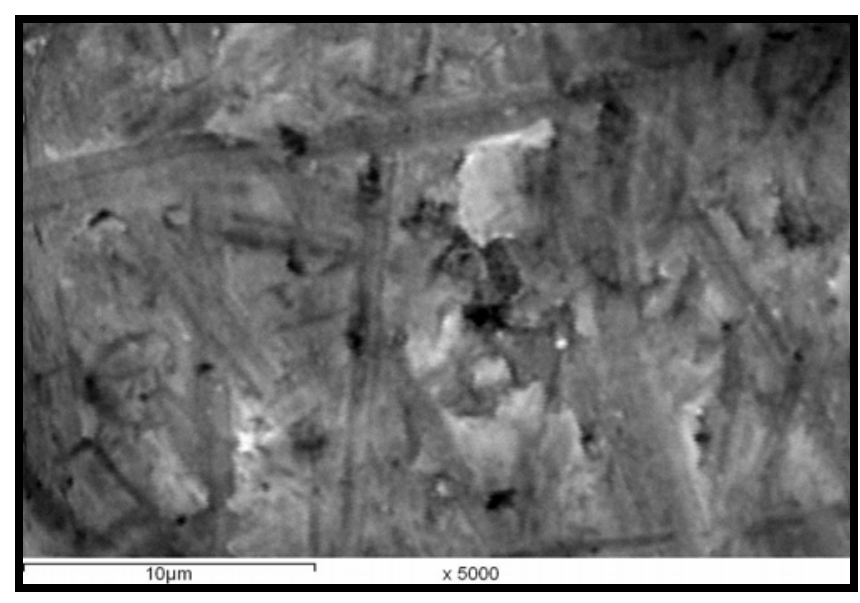

(A)

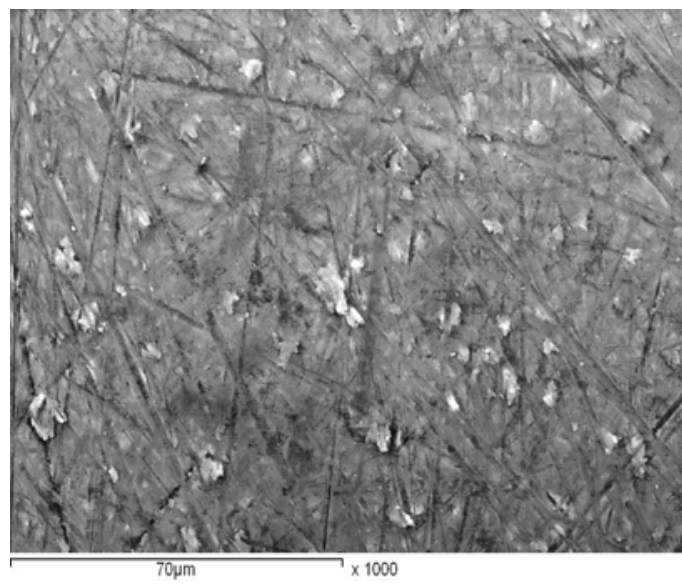

(B)

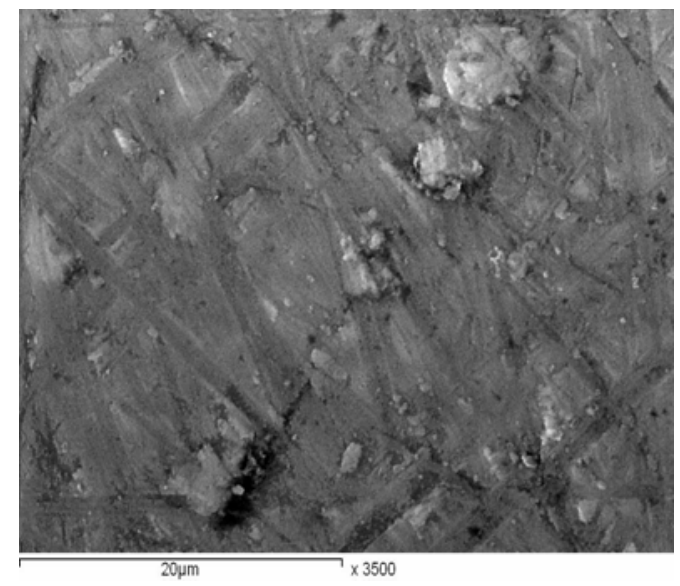

(C)

Figure 9. Surface morphology of of titanium alloy (Ti-6Al-4V) electrode

(A) in $4.0 \mathrm{M} \mathrm{NaOH}$ solution (B) in $4.0 \mathrm{M} \mathrm{NaOH}$ solution $+1 \%$ egg albumin (C) in $4.0 \mathrm{M} \mathrm{NaOH}$ solution $+1 \%$ bovine albumin 